\title{
第三次国土调查中做好地籍测绘工作的策略探讨
}

牛亚莉 12 杜祥亭 ${ }^{12}$

1 青海省地质测绘地理信息院 2 青海省高原测绘地理信息新技术重点实验室

DOI:10.32629/gmsm.v3i1.491

[摘 要] 地籍测绘工作质量直接决定着国土调查数据的精准性。国土调查作为我国一项重要的法定制度,是我国如实掌握土地资源现状的重要 方式。第三次国土调查是在第二次国土调查数据基础之上展开,有助于国家进一步掌握我国土地资源使用情况。本文对第三次国土调查中做好 地籍测绘工作策略进行了相应分析。希望可以给相关工作者带来借鉴参考价值,并促进我国土地资源得到科学合理利用。

[关键词] 第三次国土调查; 地籍测绘工作；策略

第三次国土调查工作的顺利开展, 可以给我国生态文明建设、宏观调 控、自然资源管理体制改革、国土资源空间利用等工作提供充足的数据支 持。换而言之,第三次国土调查数据的精准性将直接决定着各项工作能否 顺利进行。地籍测绘工作是国土调查的重要工作内容。通过科学合理的开 展地籍测绘, 可以最大程度上确保国土调查数据的精准性。以下内容简 单阐述了地籍测绘工作在第三次国土调查中的重要性, 并在此基础上阐 述了国土调查中地籍测量工作特点与测量方法、国土调查中做好地籍测 绘工作策略。

\section{1 地籍测绘工作在第三次国土调查中的重要性}

1. 1全面掌握国家的土地资源现状

随着我国社会经济进入新常态, 生态文明建设、自然资源资产管理体 制改革、不动产统一登记等工作逐步得到开展。而国土数据精准性与全面 性将直接影响到以上各项工作质量与效率。因此, 开展第三次国土调查, 可以帮助我国相关部门更为精准得掌握国土资源应用数量、结构分配、具 体分布与应用效果。同时, 我国政府结合相应的数据, 可以制定出适宜的土 地供给侧结构性改革方案。

\section{2增大国家耕地资源保护力度}

农业是我国第一产业, 是国民之根本。因此, 有效保护耕地资源, 方可 以更好得满足农业发展需求。随着我国城市化进程的不断加快, 以及人口 的不断增加, 我国人均耕地逐步下降。通过开展第三次国土调查, 可以帮助 我国相关部门充分得了解我国目前耕地数量与耕地利用效率, 并结合目前 实际情况制定出适宜的耕地保护措施, 实现耕地资源的优化配置。

1. 3 有效提升国土资源开发质量

随着我国城市化进程的不断加快, 以及城镇化水平的不断提升, 国土

\section{2 在土地利用监测中的应用}

需要先做好相应的数据处理工作, 包括基础地图准备、高程数据收集、 行政界线明确以及影像RPC文件整理等, 在完成数据的收集和整理后, 还需 要根据实际需求, 对数据进行预处理, 提取出土地利用的变化信息, 对土地 数据库中的信息进行及时更新, 保证数据信息的准确性和时效性。

\section{$53 S$ 技术应用的优势}

对照具体国土勘测实践项目, 对3S优势梳理如下: 一是利用网络RTK 技术, 可以实现高精度数据的采集。通常, 在界址点解析中, 精度要求是 关键。对于相邻控制点, 点位误差在 $\pm 5 \mathrm{~cm}$, 相邻误差为 $\pm 5 \mathrm{~cm}$ 。借助于多 卫星数据源, 可以有效克服单一定位系统带来的数据测量误差, 实现快 速、精准、实时定位。在遥感RS测绘中, 引入低空无人机航拍影像, 来辅 助生成各类真彩色影像图, 并结合实测地形图进行对应生成, 来调查国 土资源状况。在地理信息系统GIS应用中, 可以发挥ArcGis地类属性管理
资源供需矛盾逐步加剧。通过开展第三次国土调查, 可以帮助我国相关部 门, 结合最新的国土现状, 制定出适宜的土地资源利用策略, 进而提升国土 资源开发质量。同时, 结合第三次国土调查, 我国可以全面地掌握城镇、农 村、开发区等不同建设用地具体情况, 并最大程度发掘土地利用潜力、优 化土地资源结构。

1.4 为房地产事业持续性发展创造良好条件

首先, 土地与建筑物产权管理工作会将地籍测绘数据作为重要的决策 依据。在土地产权发生变化时, 工作人员就需要通过地籍测量数据资料来 找出登记记录与土地的权属关系。其次, 高精度的地籍测绘数据, 可以精准 得反应出各项房产间的权属界线、面积与类型, 进而给地产投资者提供充 足的信息支持。再次, 当房屋遭受灾害时, 房屋所有者可以凭借地籍测绘结 果向保险公司主张索赔。最后, 为房屋权属纠纷提供数据支持。当发生房 屋权属纠纷时, 相关机构会结合测绘部门提供的地籍测绘资料来充分地分 析权属情况, 进而提升权属纠纷案件解决质量与效率。

1.5 有助于解决一些现实问题

在国土调查中, 地籍测绘是重要的测绘工具。从行为性质来看, 地籍测 绘是一种具有一定政府行为的测绘工作。通过地籍测绘, 政府可以有效实 施土地行政管理职能。在国土调查中做好地籍测绘工作, 可以帮助国家更 好到保护士地资源, 并科学合理到利用现有土地、保护土地所有者的合法 权益, 进而促进社会经济获得可持续性、快速、健康发展。

地籍测绘是多种关系的重要核心。为了提升第三次国土调查中地籍测 绘质量, 需要严格把控地籍测绘技术水平。同时, 地籍测绘也可以更好地处 理与调节人与人、人与社会间的关系。

\section{2 国土调查中地籍测量工作特点与测量方法}

与更新优势, 实现地类属性统计显示。如各地类面积、项目用地面积统 计等。

\section{6 结语}

总之, 3S技术的应用, 利用其强大的定位功能, 为国土资源勘测、定界 提供了便捷途径。在进行实际勘测中, 要结合具体任务, 对3S技术各自的优 劣势进行整体把握, 选择合适的定位系统, 提高国土勘测精度和效率。

[参考文献]

[1]宣罗伟.浅谈3S技术在国土资源测绘中的应用[J]. 华北国土资 源,2018(01):122-123.

[2]郑浩然, 崔志喜, 李永学. 关于国土资源测绘过程中3S技术应用对策 [J].西部资源,2016(06):127-128+166.

[3]冯晓.3S技术在国土资源执法监察工作中的应用[J].工程建设与设 计,2018(04):269-270. 
2. 1 测量特点

在国土调查中, 为了便于地籍测量管理工作的顺利开展, 工作人员需 要在土地权属之上, 以及某些区域范围内, 选择适宜的测量技术、测量仪器 与测量方法, 来将每块土地权属界线、类型、位置等测量清楚, 并结合测量 数据计算出各块土地面积, 进而绘制出地籍图, 为土地登记工作的顺利开 展提供充足的依据。

\section{2 地籍测量方法}

在地籍测量中, 按照测量设备类型, 可以将测量方法划分为普通测量 法、航测量法与综合测量法。按照地籍图成图方式来看, 可以将地籍测量 划分为解析法、部分解析法与图解法。为了提升地籍测量结果精准性, 在 具体测量工作中, 工作人员需要依托地籍调查表与宗地草图来开展具体的 测量工作, 进而来为土地登记工作提供充足的数据支持。

\section{3 国土调查中做好地籍测绘工作的策略}

地籍测绘是国土调查的重要工作内容。高质量的地籍测绘工作, 可以 给国土调查工作打下坚实基础。反之, 当地籍测绘工作质量欠佳时, 也将会 影响到国土调查质量与调查效率, 进而无法为国民经济各项相关工作提供 精准的国土数据支持。因此, 在第三次国土调查中, 有效做好地籍测绘工作 就显得尤为重要。以下内容阐述了地籍测绘工作策略。

3. 1 科学合理地利用GPS技术

GPS即全球定位系统。由于此项技术具有着测量时间短、定位精度高、 操作自动化等诸多优势, 使得此项技术在地籍测量中得到了广泛应用, 并 大力提升了地籍测量质量与测量效率。在第三次国土调查中, 将GPS技术应 用于地籍测绘中时, 主要用来采集数据信息, 并将所采集到得数据进行有 效存储。相较于传统的测绘技术, GPS技术在地籍测绘中的应用, 可以大力 提升地籍测绘质量与测绘效率, 并有效降低测绘成本。

3. 2 科学合理地运用业内扫描测量数字化技术

业内扫描测量数字化技术在地籍测量工作中的应用, 主要用来采集地 形图与地籍图。同时, 工作人员可以结合坐标数据进行有效计算。在地籍 测量中, 数字化扫描测绘技术多是以准地籍形式出现。然而, 现实中, 此种 方式很容易影响到测绘精度与测绘标度。为了提升测量质量, 工作人员可 以在后续的地籍调查或者变更填充时进行相应补充。

3. 3城市建设中地籍测绘应用

随着我国城市化进程的加快, 以及城镇化水平的逐步提升, 国家整体 的土地资源所需量逐步增加。为了提升城镇周边土地的利用效率, 就需要 在国土调查中对城镇周边土地展开地籍情况调查。同时, 在遵守相应法律
法规定的基础之上, 将集约化的经营模式应用于土地经营中, 可以大力提 升城镇周边土地的整理体用率。从整体情况来看, 通过将地籍测绘应用于 城市建设中, 实现了城建土地资源优化配置, 并提升了土地资源利用率, 将 土地资源的潜在价值充分到挖掘出来, 进而促进社会经济后的可持续性、 快速、健康发展。

3.4 建设用地勘定测绘中遥感技术的应用

为了确保建设用地勘测界定质量, 测量团队往往会聘请一些高技术水 平、测量经验丰富的工作人员参加到勘测界定工作中。尽管此种勘定方式 在实际工作中得到了一定程度的应用, 但是此种传统的勘定方式, 对测量 人员的技术水平要求较高, 且在一些较为恶劣的环境中, 很难把控测量数 据精准度。随着科学技术的快速发展, 遥感技术在国土调查地籍测绘中得 到了广泛应用。主要是由于此项技术不易受到外在环境影响, 而且可以有 效规避关系放样方法与解析法的复杂性。同时, 遥感技术在地籍测量中的 应用, 精简了公路、铁路等建设用地的勘定工作程序, 进而减少地籍勘测工 作人员的劳动量, 并节约了工程所需成本投入, 提升了工程经济效益。

\section{4 结束语}

总之, 随着我国城市化进程的不断加快, 以及社会经济的快速发展, 国家整体的土地资源需求量逐步增加。从法律层面来看, 国土调查已成 为我国各级政府的一项法律行为。在国土调查中, 地籍测绘是其重要工 作内容。通过提升地籍测绘工作质量, 则可以最大程度上确保国土调查数 据的精准性。以上内容阐述了第三次国土调查中地籍测绘工作的重要性, 并阐述了国土调查中地籍测量工作特点与测量方法与地籍测绘工作策略。 希望可以给相关工作者带来借鉴参考价值, 并充分发挥出我国国土资源的 潜在价值, 实现我国国土资源的优化配置, 促进社会经济获得可持续性、快 速、健康发展。

\section{[参考文献]}

[1]吴桂华, 吴溪.刍议土地调查中地籍测绘技术的应用 [J].吉林农 业,2019(7):48

[2]党文强.谈如何做好第三次全国土地调查工作 [J].中国标准 化,2019(4):224-225.

[3]吴勇.刍议新时期如何做好日常土地测绘工作[J].中国房地产业: 理论版,2012(7):480.

[4]刘美玲.关于地籍调查中数字地籍测绘应用的几点探讨[J].科学与 财富,2015(28):158-159. 